\title{
Control for Grid Connected and Intentional Islanding of Distributed Power Generation
}

\author{
Ruchali Borkute' ${ }^{1}$ Nikita Malwar ${ }^{2}$ \\ 1PG Student, ${ }^{2}$ Assistant Professor \\ 1,2Department of Electrical Engineering, T.G.P.C.E.T. Mohgaon, Nagpur, Maharashtra, India
}

\begin{abstract}
How to cite this paper: Ruchali Borkute | Nikita Malwar "Control for Grid Connected and Intentional Islanding of Distributed Power Generation" Published in International Journal of Trend in Scientific Research and Development (ijtsrd), ISSN: 24566470, Volume-3 | Issue-4, June 2019, pp.333-336, URL: https://www.ijtsrd.c om/papers/ijtsrd23 679.pdf

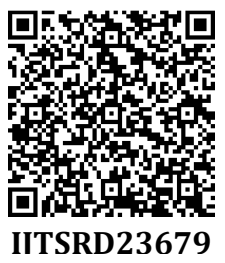

Copyright (c) 2019 by author(s) and International Journal of Trend in Scientific Research and Development Journal. This is an Open Access article distributed under the terms of the Creative Commons

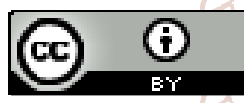
Attribution License (CC BY 4.0) (http://creativecommons.org/licenses/ by $/ 4.0$ )

\section{ABSTRACT}

As the demand for more reliable and secure power system with greater power quality increases, the concept of distributed generation (DG) have become more popular. This popularity of DG concept has developed simultaneously with the decrease in manufacturing costs associated with clean and alternative technologies like fuel cells, biomass, micro-turbine and solar cell systems. Intentional islanding is the purposeful sectionalisation of the utility system during widespread disturbances to create power "island". This island can be designed to maintain a continuous supply of power during disturbances of the main distribution system.

Keywords: DG-Distributed Generation, grid connected operations Intentional islanding

\section{INTRODUCTION}

Small localized power sources, commonly known as "DG" has become a popular alternative to bulk electric power generation. Electrical utilities are becoming more and more stressed since existing transmission and distribution system are facing there operating constraints with growing load. There are many reasons for the growing popularity of DG; however on top of DG tending to be more renewable, DG can serve as a cost effective alternative to major system upgrade for peak shaving or enhancing load capacity margin. Recent innovations in power electronics such as fast switching mosfet and development in power generation technologies have made DG a considerable alternative to either delaying infrastructure upgrades or as additional cogeneration support.
The commonly used distributed resources are wind power, photo voltaic, hydro power. Distributed generation has become an important factor while considering intentional islanding to the problem. Intentional islanding describe the condition in which a micro-grid or portion of power grid which consist of load and dg system is isolated from the power system. In this situation it is important for micro-grid to continue to provide adequate power to the load. In this paper we have shown the intentional islanding and the software which we going to simulate in this model is matlab/simulink.

\section{The Distributed Generation system}

The distributed generation system includes a PV sources, inverter, filter. The pv source voltage which is dc is inverted to get smooth three phase sinusoidal waveform. The self commutated inverter uses mosfet as a switching device. The transients present in the inverter output are suppressed by using filter circuit. The load is supplied at grid voltage and frequency. If suppose dg is islanded from rest of the network, the voltage and frequency deviates from the original value. The controllers should detect the islanding and adjust the inverter output voltage and frequency. The conversion of dc to ac I done by using inverter. The mathematical modeling pg pv cells can be formed by using single diode module as shown in fig 1 . Solar cell can operate with maximum efficiency at particular operating point. Therefore it is basic need to track the maximum power point at any irradiance or temperature condition.

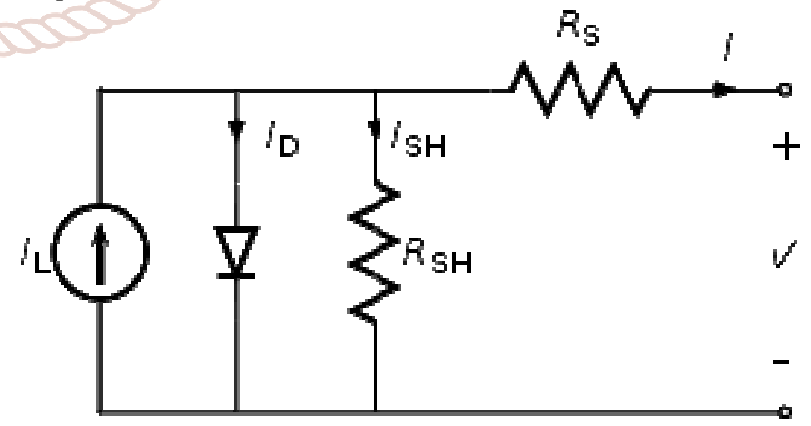

Fig 1. Solar cell ckt diagram

III. MICRO-GRID CONFIGURATION AND FEATURES

The fundamental miniaturized scale network engineering graph as appeared in figure1. As appeared in this figure comprises of four feeders and appropriation framework. The A , B and C feeders are touchy burden and it required neighborhood age yet some of non-delicate advertisement it don't required any sort nearby age. In this framework comprise of four smaller scale sources at hub 8, 11, 22, and 16. At the point when the issue emerges in the utility network then the static switch is open and detached the 
touchy burdens from the fundamental framework. At the point when the small scale network is framework associated control streaming the non-delicate burdens. The smaller scale framework comprises of ace controller or focal controller. It is controlling the task of smaller scale framework. This framework is arranged into three classes.

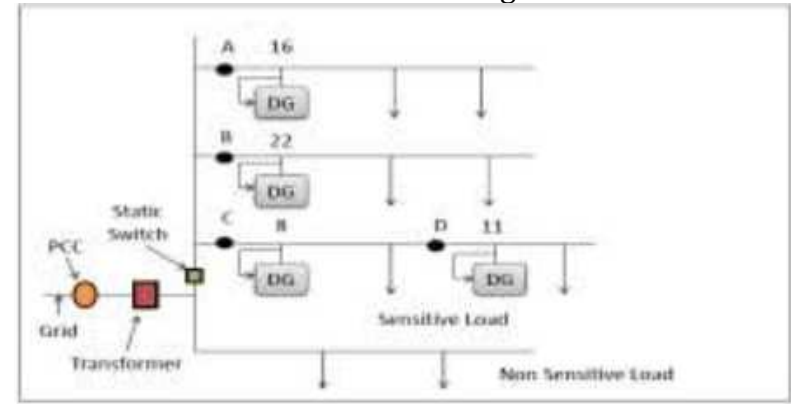

Fig2. Basic Micro-grid architecture

\section{Islanding Concept}

Islanding is a condition in which the DG continues to supply power to the location even though electrical grid power is no longer present. There are two types of islanding modes mainly, Intentional islanding that is planned and unintentional islanding that is unplanned. The purpose of intentional islanding is to sectionalize the utility system in order to create a power island during an occurrence of disturbances. There are different methods available in the literature to detect islanding. They are mainly local method and remote methods. Remote methods are based on the communication between local DG and the utility grid where as local methods rely on monitoring parameters like voltage and frequency at the DG sites..

\section{Simulation system and discussion}

As we can see from fig 2 which is a complete simulation model of the project, the pv system consist of the pv panels which are connected in parallel with each other. Each single panel consist of six arrays. This panel are connected to voltage sensors and current sensors to calculate the generating voltage and current. Current and voltage is been measure using current measurement and voltage measurement. The solar panels are connected to mppt. The mppt is been done by using the perturb and observe method. Fig 3 shows the mppt model in simulation. The boost convert is been made to boost the generation of the voltage.The inverter which mainly consist of six pulse generation by using the switching device which is mosfet. The maximum amount of unused power is stored in the battery. The nickel metal hydride type of battery is been used which has the maximum capacity.The bus system is been made which has several loads connected to it.

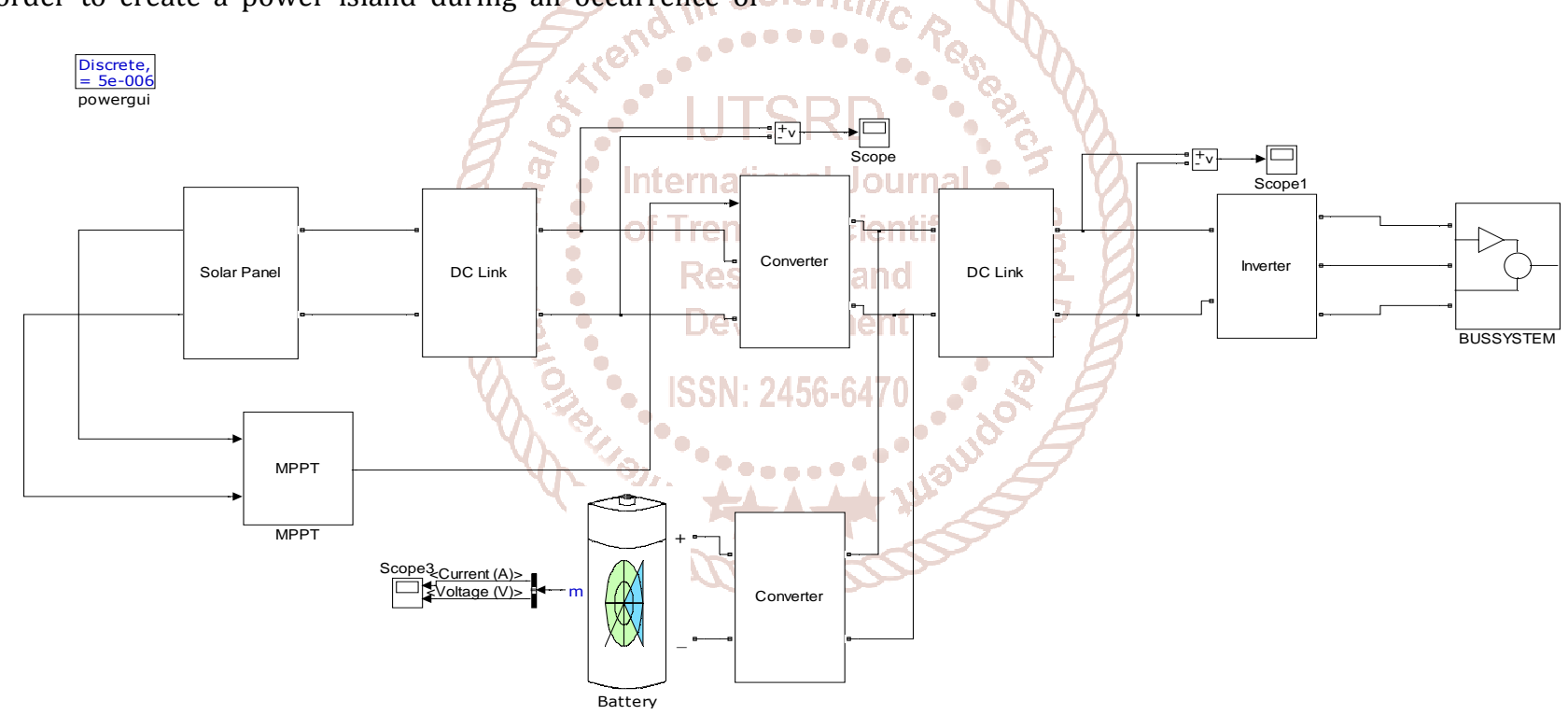

Fig 2. Complete model

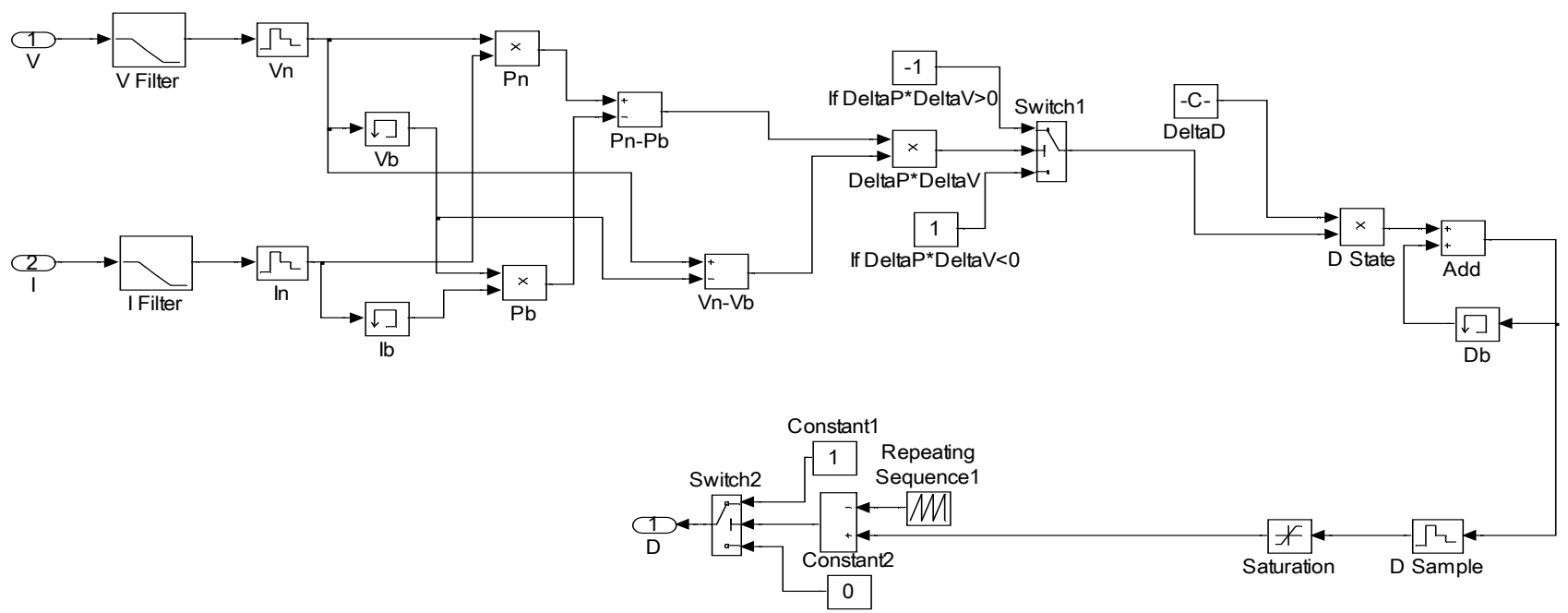

Fig 3. MPPT Simulation 
V

Simulation result
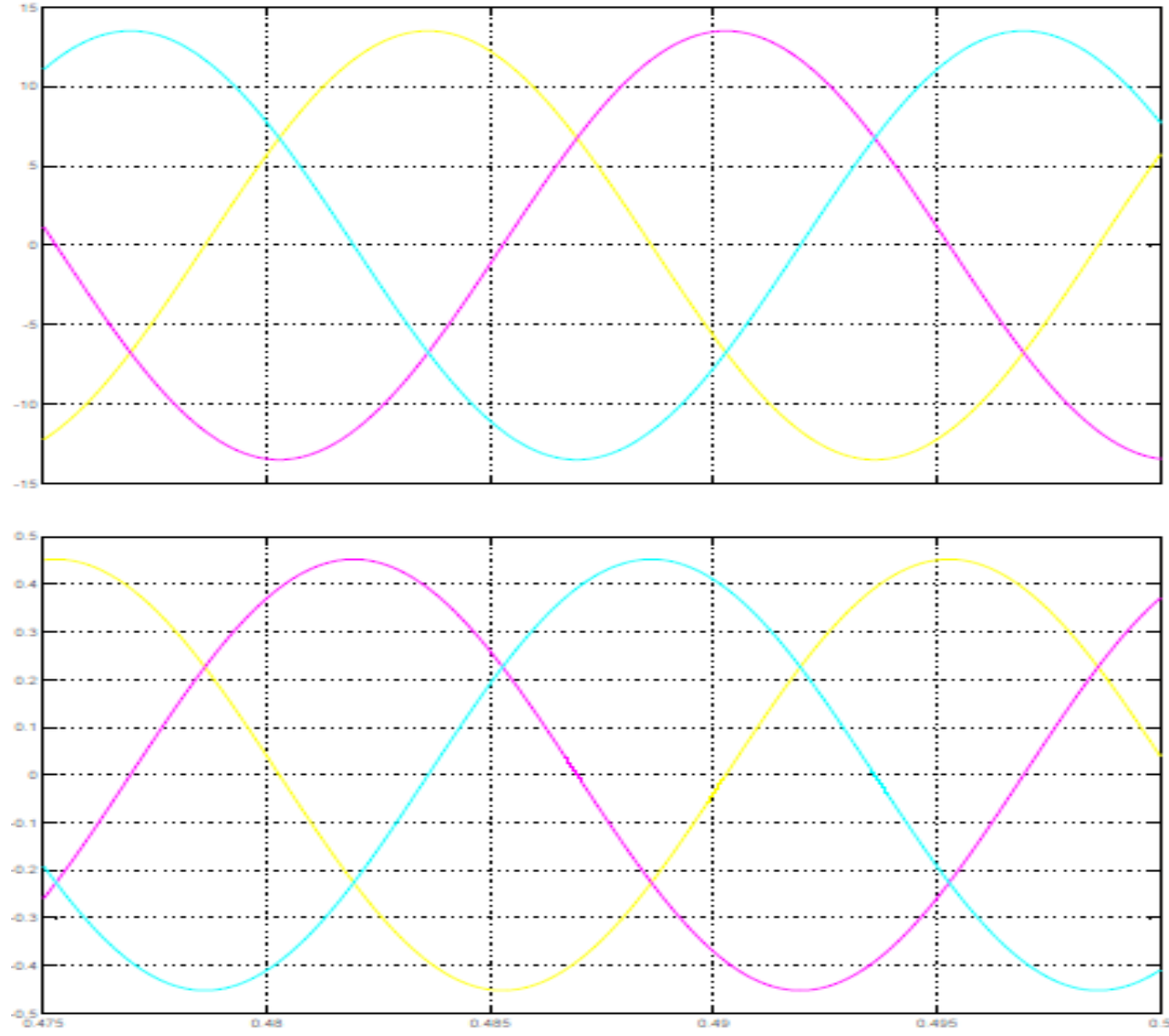

VII. Conclusion:-

In this paper we have develop a current and voltage control techniques for the grid connected system and intentional islanding has done for the operation of the system. The DG system is synchronized with the micro grid and the main power grid and the performance of the micro grid has been evaluated, analyzed and determined using effective use of MATLAB/SIMULINK. The grids connected mode with the help of the intentional islanding can be synchronized with the

1. Power Quality

2. Loss of main detection

3. Load shedding

\section{References:-}

[1] Rashad M. kamel, "Maintaining stability of standalone Micro grid by employing electrical and mechanical fault ride through techniques upon fixed speed wind generation system", Energy Conversion and management, pp 149-1612013.

[2] Gaurav.K.Kasal and Bhim singh, "Voltage and Frequency Controller for an Asynchronous Generator-Based Isolated Wind Energy Conversion System", IEEE Transation on Energy Conversion, Vol. 26, no. 2, June 2011.

[3] P. K. Goel, B. singh, S. S. Murthy and N. Kishore, "Isolated Wind-Hydro Hybrid System Using Cage Generators and Battery Storage", IEEE Transactions on Industrial Electronics,vol.58, no.4, April 2011.
[4] V. Rajagopal, Bhim Singh, "Design of a stae-Hexagon Transformer based Electronic Load Controller for isolated Pico Hydro Generating System", third International Conference on power Systems, Kharagpur, pp no.153, Dec 2009.

[5] R. H. Lasseter, "Micro grids(distributed power generation)", IEEE Power Engineering Society Winter Meeting,vol.01, pp.146-149, Columbus,ohio, feb 2001.

[6] F. Katiraei, M. R. Iravani and P. W. Lehn, "Micro grid Autonomous operation During and Subsequent to Islanding Process", IEEE Trans. on power Delivery, vol.20, no.1, Jan 2005.

[7] Changhee Cho, Jin-Hong Jeon, Jong-Yul Kim, Soonman Kwon, Kyongyop Park and Sungshin Kim, "Active Synchronizing Control of a Microgrid", IEEE Transaction on power Electronics, vol.26, pp 12, Dec 2011.

[8] Irvin J. Balaguer, Qin lei, Shuitao Yang, uthane Supatti and Fang Zheng Peng, "Control for Grid Connected and Intentional Islanding Operation of Distributed Power Generation", IEEE Transaction on Industrial Electronics, vol.58, no.1, Jan 2011.

[9] Shivkumar V Iyer, Madhu N. Belur and Mukul C. Chandorkar, "Analysis and mitigation of voltage offsets in multi-inverter micro grid", IEEE Transaction on Energy Conservation, vol. 26, no 1, March 2011. 
International Journal of Trend in Scientific Research and Development (IJTSRD) @ www.ijtsrd.com eISSN: 2456-6470

[10] Massucco, S,; Pitto, A, ;Silvestreo, F. A. Gas turbine model for studies on distributed generation penetration into distributed network, IEEE Trans. Power Syst.2011, 26, 992-999.

[11] Balaguer, L; Lei, Q.; Yang, s,; Supatti, U,; Peng, F. Z. Control for Grid Connected and Intentional Islanding Operation of Distributed Power Generation. IEEE Transaction.Ind.Electron.2011, 58, 147-157.

[12] Chen, $\mathrm{Y}$,; $\mathrm{Xu}, \mathrm{Z}$;; Ostergaard, J. Frequency analysis for planned islanding operation in the Danish distributed system-Bornholm. In Proceeding of the 43rd International Universities Power Engineering Conference,UPEC,Padova,Italy,1-4 September 2008; pp.1-5.

[13] Shahabi, M,; Haghifam, M. R,; Mohamadian, M,; NabaviNiaki,s. Dynamic behaviour improvement in a microgrid with multiple DG units using a power sharing approach. In proceeding of the IEEE Bucharest Power Tech,Bucharest,Romania,28 June 2009; pp.1-8.

[14] Mulhausen,J,;Schaefer,J,;Mynam,M,;Guzman,A,;Donolo, M.Anti-islanding today, successful islanding in the future. In Proceeding of the 63rd Annual Conference for Protective Relay Engineers, College Station, TX, USA, 29 March-1 April 2010; pp.1-8.
[15] Mohomad, H,; Mokhlis, H,; Bakar, A. H. A,; Ping, H. W. A review on islanding operation and control for distributed network connected with small hydro power plant. Renew. Sustain. Energy Rev.2011, 15,3952-3962.

[16] Trujillo, c.;Velasco, D.; Figueres, E; Garcera, G. Local and remote techniques for islanding detection in distributed generators. In Distributed Generation; In Tech publication;Rijeka,croatia,2010; Chapter 6 .

[17] Mahat, p,; Chen, Z,; Bak-Jensen, B. Review of islanding detection methods for distributed generation. In Proceeding of the 3rd International Conference on Electric Utility Deregulation and Restructuring and power Technologies,DRPT,Nanjing,China,6-9 April 2008;pp.2743-2748.

[18] Maki, K,; Kulmala, A.; Repo, S.; Jarventausta, P. Problems related to islanding protection of distributed generation in distributed network. In Proceeding of the IEEE Power Tech,Lausanne,Switzerland,1-5 july 2077; pp.467-472.

[19] Velasco, D.; Trujillo, c.; Garcera, G.; Figueres, E. Review of anti-islanding techniques in distributed generators. Renew. Sustain. Energy Rev.2010, 14, 1608-1614.

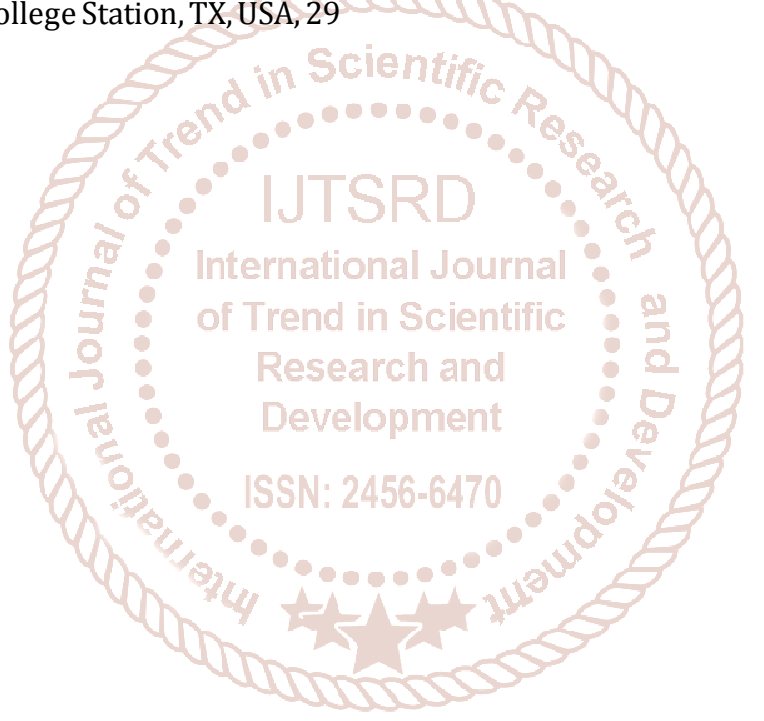

